\title{
The System of Indicators of Enterprise's Innovative Activity
}

\author{
Faizrahmanova G. R. ${ }^{1} \&$ Kozlova N. N. ${ }^{1}$ \\ ${ }^{1}$ Kazan Federal University, Institute of Management, Economics and Finance, Kazan, 420008, Russia \\ Correspondence: Faizrahmanova G. R., Kazan Federal University, Institute of Management, Economics and \\ Finance, Kazan, 420008, Russia.
}

Received: March 10, 2015 Accepted: March 31, 2015 Online Published: April 30, 2015

doi:10.5539/ass.v11n11p183

URL: http://dx.doi.org/10.5539/ass.v11n11p183

\begin{abstract}
An innovative directivity of the modern economy development requires activation of researches in the field of the analysis of organization's innovative activity. The complex assessment of innovative activities is possible only with using system of indicators of innovative activity and scales of enterprise's innovative activities, its innovative potential, and also a retrospective and perspective assessment of innovative activities' efficiency.
\end{abstract}

Keywords: innovative activities, innovative activity, scales of innovative activities, innovative potential, efficiency of innovative activities, indicators of innovative activity, economic effect, expenses on innovative activity

\section{Introduction}

One of the most important tasks of control of innovative organization activity is the analysis of its feasibility, and also productivity of innovative activities and its certain directions. For intensification of transition of organizations' economy to innovative type of development it is necessary to activate researches in the field of innovative enterprises' activity, its innovative potential, and also increase of innovative activities' efficiency. Implementation of organization's innovative activity is directed on achievement of certain economic results, the solution of tasks of economic and financial development. This requirement finds expression as a part of innovative activities' indicators (Akhtyamova, Domracheva, \& Yakovlev, 2014, p. 225). The assessment of enterprise's innovative activities assumes multiaspect research on detection of tendencies and perspectives of further development of innovative processes and their influence on the enterprise' economy. In this regard it is actually to form the indicators system of innovative activities orienting on the state and business modern requirements. Thus, speaking about innovative activities, more pertinently to apply the concept "indicator" (from Latin. indicator - the pointer) - the orienting economic index, the measuring instrument, allowing in a certain level to foresee in what direction should expect development of economic processes (Suellen \& Leonard, 2014).

\section{Theory}

It is expedient to realize the system research of organization's innovative activity on the basis of three groups of interdependent indicators which most general sequence of application is presented in a figure 1. In some cases it can be changed (Nesterov \& Neizvestnaya, 2014, p. 163).

Indicators of innovative activity and its scales reflect the character and intensity of innovative activities, and also its scales. It is possible to select absolute and relative indicators in each of the presented six subgroups.

Innovative activity in many respects depends on the organization's innovative potential; in this connection it is necessary to select indicators of innovative potential in separate group. If the organization's innovative potential is higher than its innovative activity, it is need to point out the existence of unused innovative opportunities. In turn, the high level of innovative activity is a factor of saving and increase of innovative potential (Uyarra, Edler, Garcia-Estevez, Georghiou, \& Yeow, 2014).

The enterprise's innovative potential is an integral characteristic of existence of real opportunities and possession of cumulative abilities for supporting effective innovative development on the basis of the synergy effect arising in case of interaction of its components (enterprise's innovative capacity) among its selves and with the components of innovative potential of the region, branch, the country and the world. The absence or the low level of one innovative potential component occasionally can become the decisive factor hindering implementation of innovative activities in this connection the innovative potential assessment is the most 
important direction of the analysis of innovative activities that requires an assessment of all above-mentioned indicators (Meleshenko \& Usanova, 2014, p. 179).

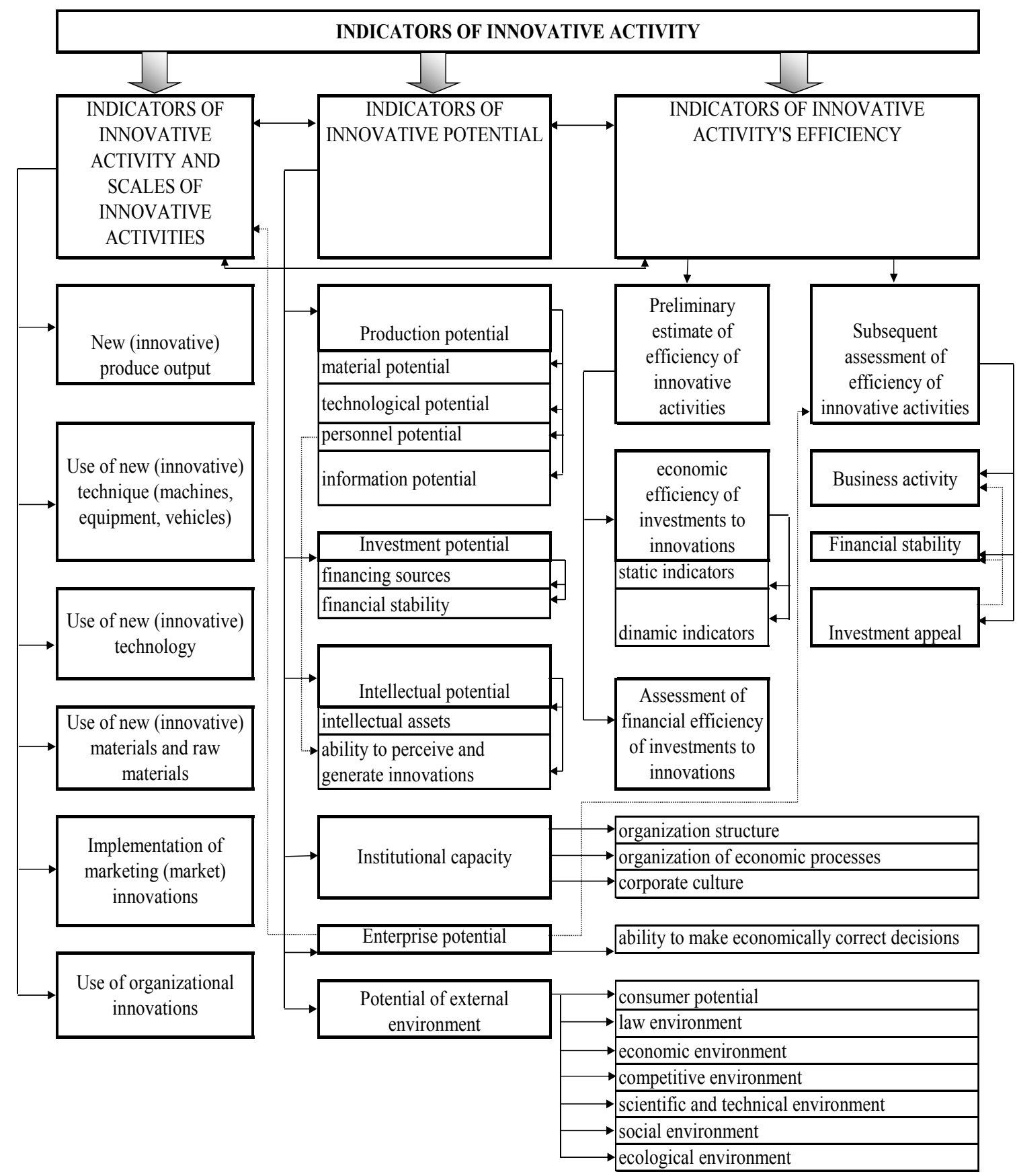

Figure 1. System of indicators of innovative activities

The important place in the analysis of innovative activities is taken by the analysis of its efficiency which is understood as a level of the best results achievement with smallest expenses. Efficiency of innovative activities is characterized by group of indicators which can be perspective and retrospective. The selected subgroups of indicators of the innovative activities' efficiency subsequent assessment characterize in general organization's financial situation and financial results of its activities in which, eventually, the results of innovative activities find reflection.

The particular interest and the significance represents by the forecast analysis of innovative activities efficiency as it provides relevant information for making of efficient decisions on feasibility of implementation of the innovative activities certain directions (Mina, Bascavusoglu-Moreau, \& Hughes, 2014). Perspective analysis of 
efficiency innovations implementation should be carried out as at the initial stage of innovative project implementation, and on completion of each stage, that is before the next stage of innovative process, for the purpose of a constant control of efficiency and feasibility of continuation innovative project implementation.

Versatility of innovations and wide-range of innovative activities cause need using of different indicators in relation to the innovative activities certain directions. Despite it, the existence of tight correlation and interconditionality of innovative and investment processes is the reason of similarity of indexes' composition for an assessment of its efficiency. At the same time the specific nature of innovations requires specification of the list of efficiency innovative activities' indicators, and also a technique of its calculation in relation to the directions of innovative activities, stages of its implementation, objects of innovative process. So, for example, efficiency indicators of output of innovative production are inapplicable to organizational innovations, and efficiency of marketing innovations can't be estimated on the basis of productivity indicators using new types of raw materials and materials (Kharisova \& Kozlova, 2014).

The general for all innovative activities indicators of economic efficiency is that it reflects a ratio between the economic effect gained from innovative activities, and the expenses connected to its implementation. Thus the most problem is the assessment of economic effect expected value that is connected with two main factors. Firstly, not always economic effect value can be measured quantitatively, secondly, often it is impossible to separate the income from innovative activities from the cumulative income of the organization. Besides, complexity of market conditions and uncertainty of innovative activities complicate forecast of possible economic effect value, and there is the absence of data for the previous periods often does impossible application of forecasting methods which are considered as a most exact, for example, such as the analysis of time series dynamics. In this regard experts should apply preferentially qualitative methods which are based on experience and intuition of analysts, but not on mathematical dependences (Lee, Park, Yoon, \& Park, 2010).

\section{Method}

Economic effect of innovative activities can be in the form of the additional income and (or) lowering of expenses as a result of innovative actions (as Figure 2).

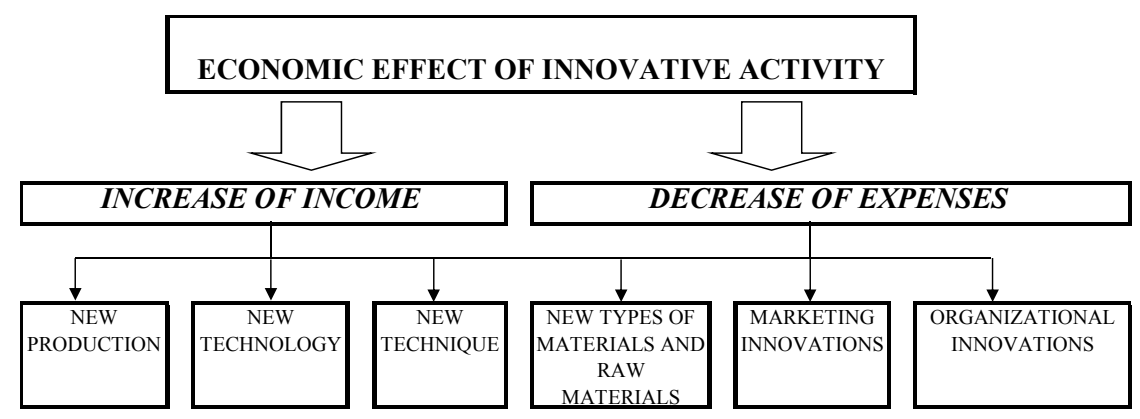

Figure 2. Economic effect of innovative activities

Costs of innovations are dispersed on different accounts, in different accounting registers, its can have the current and capital character. Besides, employees who are, as a rule, involved in primary activity are also take part in innovative process. In innovation process uniform objects of fixed assets are also used, there are other overhead costs, in this connection there is a question of their distribution. However in case of the appropriate management accounting organization of innovative activities expenses, implementation of effective system of budgeting, use of reasonable forecasting methods of expenses, complex calculation and an assessment of innovative project implementation costs is represented to us quite available and real on condition of comprehensive implementable project research (Strelnik, Usanova, \& Ushakova, 2014, p. 16).

\section{Results}

In Table 1 the main indicators of efficiency in the directions of innovative activities within perspective analysis which can be absolute and the relative, determined and stochastic are provided.

Calculation formulas of the presented indicators of the forecast analysis of innovative activities efficiency are shown in a Figure 3. Most precisely the level of innovative activities efficiency can be predicted on the basis of complex use of this group of indicators (Ushakova, Safiullin, \& Strelnik, 2014). 
Table 1. Indicators of the forecast analysis of innovative activities efficiency

\begin{tabular}{|c|c|c|c|c|c|c|c|c|}
\hline \multirow[t]{2}{*}{ Indicators } & \multicolumn{2}{|c|}{$\begin{array}{l}\text { Characteristic of } \\
\text { indicator }\end{array}$} & \multicolumn{6}{|c|}{ Directions of innovative activities } \\
\hline & abs./rel. & $\begin{array}{c}\text { determ./st } \\
\text { ochastic }\end{array}$ & $\begin{array}{c}\text { new } \\
\text { production }\end{array}$ & $\begin{array}{c}\text { new } \\
\text { technology }\end{array}$ & \begin{tabular}{|c|} 
new \\
technique
\end{tabular} & $\begin{array}{c}\text { new types } \\
\text { of materials } \\
\text { and raw } \\
\text { materials }\end{array}$ & $\begin{array}{l}\text { marketing } \\
\text { innovations }\end{array}$ & $\begin{array}{c}\text { organizational } \\
\text { innovations }\end{array}$ \\
\hline $\begin{array}{l}\text { Innovative activity profit } \\
\text { (Pia) }\end{array}$ & abs. & determ. & + & + & + & + & + & + \\
\hline $\begin{array}{l}\text { Profitability of investments } \\
\text { to innovations (Ri) }\end{array}$ & rel. & determ. & + & + & + & + & + & + \\
\hline $\begin{array}{l}\text { Profitability of innovative } \\
\text { activity (Ria) }\end{array}$ & rel. & determ. & + & + & + & + & + & + \\
\hline $\begin{array}{l}\text { Profitability of new } \\
\text { production (Rpr.) }\end{array}$ & rel. & determ. & + & & & & & \\
\hline $\begin{array}{l}\text { Profitability of innovative } \\
\text { assets (Ria) }\end{array}$ & rel. & determ. & & + & + & & & \\
\hline $\begin{array}{l}\text { Innovation cost repayment } \\
\text { time }(\mathrm{T})\end{array}$ & rel. & determ. & + & + & + & + & + & + \\
\hline Net present value (NPV) & rel. & stohastic & + & + & + & + & + & + \\
\hline $\begin{array}{l}\text { Internal (accounting) rate of } \\
\text { return (IRR, ARR) }\end{array}$ & rel. & stohastic & + & + & + & + & + & + \\
\hline $\begin{array}{l}\text { Discounted Pay-back Period } \\
\text { (DPP) }\end{array}$ & rel. & stohastic & + & + & + & + & + & + \\
\hline Profitability index (PI) & rel. & stohastic & + & + & + & + & + & + \\
\hline
\end{tabular}

\begin{tabular}{|c|c|c|c|c|c|}
\hline Indicators & $\begin{array}{c}\text { Innovative activity } \\
\text { profit (Pia) }\end{array}$ & $\begin{array}{c}\text { Profitability of } \\
\text { investments to } \\
\text { innovations (Ri) }\end{array}$ & $\begin{array}{c}\text { Profitability of } \\
\text { innovative activity } \\
\text { (Ria) }\end{array}$ & $\begin{array}{c}\text { Profitability of } \\
\text { new production } \\
\text { (Rpr.) }\end{array}$ & $\begin{array}{c}\text { Profitability of } \\
\text { innovative assets } \\
\text { (Ria) }\end{array}$ \\
\hline $\begin{array}{c}\text { Calculation } \\
\text { formulas }\end{array}$ & $E E_{i a c}-C_{i a c}$ & $P_{i p} / C_{i a c}$ & $P_{i p} / E E_{i a c}$ & $P_{i p} / S_{i p}$ & $P_{i a s} / I A_{s}$ \\
\hline Indicators & $\begin{array}{c}\text { Innovation cost } \\
\text { repayment time (T) }\end{array}$ & Net present value (NPV) & $\begin{array}{c}\text { Internal (accounting) rate of return } \\
\text { (IRR, ARR) }\end{array}$ \\
\hline $\begin{array}{c}\text { Calculation } \\
\text { formulas }\end{array}$ & $C_{i a c} / E E_{i a c}$ & $\sum_{t=0}^{T} \frac{E E_{i a c}(t)}{(1+\mathrm{r})^{t}}-\sum_{t=0}^{T} \frac{C_{i a c}(t)}{(1+\mathrm{r})^{t}}$ & $\sum_{t=0}^{T} \frac{E E_{i a c}(t)}{(1+\mathrm{IRR})^{t}}-\sum_{t=0}^{T} \frac{C_{i a c}(t)}{(1+\mathrm{IRR})^{t}}=0$ \\
\hline $\begin{array}{c}\text { Indicators } \\
\text { Discounted Pay-back Period (DPP) }\end{array}$ & $\begin{array}{c}\text { Profitability index (PI) } \\
\text { falculation } \\
\text { formulas }\end{array}$ & $\sum_{t=0}^{T} \frac{E E_{i a c}(\mathrm{DPP})}{(1+\mathrm{r})^{\mathrm{DPP}}}-\sum_{t=0}^{T} \frac{C_{i a c}(\mathrm{DPP})}{(1+\mathrm{r})^{\mathrm{DPP}}}=0$ & $\sum_{t=0}^{T} \frac{E E_{i a c}(t)}{(1+\mathrm{r})^{t}} / \sum_{t=0}^{T} \frac{C_{i a c}(t)}{(1+\mathrm{r})^{t}}$ \\
\hline
\end{tabular}

$\mathrm{EE}_{i a c}$ - economic effect of innovative activity;

$\mathrm{C}_{i a c}$ - costs of innovative activity implementation;

$\mathrm{P}_{i p}$ - profit on innovative production sales;

$\mathrm{S}_{i p}$ - innovative production sales revenue;

$\mathrm{P}_{\text {ias }}$ - profit on innovative assets using;

IAs - cost of innovative assets;

$\mathrm{t}$ - project timeline;

$r$ - rate of discounting.

Figure 3. Calculation formulas of indicators of innovative activities efficiency 


\section{Conclusions}

Thus, the offered system of indicators of innovative activities will allow in a complex, comprehensively to analyze innovative activity and scales of organization's innovative activity, to evaluate its innovative potential, and also to give the subsequent and perspective assessment to innovative activities efficiency that is pledge of successful innovative development (Vetoshkina \& Tukhvatullin, 2014).

\section{References}

Akhtyamova, A. Sh., Domracheva, E. S., \& Yakovlev, V. U. (2014). Management of Expenses of the Commercial Organization for Increase of its Business Activity. World Applied Sciences Journal, 27(Economics, Management and Finance), 224-228.

Dahlander, L., \& M.Gann D. (2010). How open is innovation? Research Policy, 39(6), 699-709. http://dx.doi.org/10.1016/j.respol.2010.01.013

Kharisova, F. I., \& Kozlova, N. N. (2014). Applying the Category of "Assertions (or Preconditions)" In Audit of Financial Statement. Mediterranean Journal of Social Sciences, 5(24), 180. http://dx.doi.org/10.5901/mjss. 2014.v5n24p180

Lee, S., Park, G., Yoon, B., \& Park, J. (2010). Open innovation in SMEs - An intermediated network model. Research Policy, 39(2), 290-300. http://dx.doi.org/10.1016/j.respol.2009.12.009

Meleshenko, S. S., \& Usanova, D. S. (2014). Methodological Approaches to the Assessing of the Quality of Audit Sampling. Mediterranean Journal of Social Sciences, 5(24), 176-180. http://dx.doi.org/10.5901/ mjss.2014.v5n24p176

Mina, A., Bascavusoglu-Moreau, E., \& Hughes, A. (2014). Open service innovation and the firm's search for external knowledge. Research Policy, 43(5), 853-866. http://dx.doi.org/10.1016/j.respol.2013.07.004

Nesterov, V. N., \& Neizvestnaya, D. V. (2014). Application of Optimization Models in Prediction of Inland Water Transport Organizations' Profit. Mediterranean Journal of Social Sciences, 5(24), 160-165. http://dx.doi.org/10.5901/mjss.2014.v5n24p160

Strelnik, E. U., Usanova, D. S., \& Ushakova, T. V. (2014). Relationship between Financial Indicators of a Company and the ERP-System Implementation Costs. Mediterranean Journal of Social Sciences, 5(24), 15-20. http://dx.doi.org/10.5901/mjss.2014.v5n24p15

Suellen, J. H., \& Leonard, V. C. (2014). Organizational culture, innovation, and performance: A test of Schein's model. Journal of Business Research, 67(8), 1609-1621. http://dx.doi.org/10.1016/j.jbusres.2013.09.007

Ushakova, T. V., Safiullin, A. R., \& Strelnik, E. U. (2014). Small and Medium Businesses Informatization Managment: Main Trends of Development in Russia. Mediterranean Journal of Social Sciences, 5(24), 165-170. http://dx.doi.org/10.5901/mjss.2014.v5n24p165

Uyarra, E., Edler, J., Garcia-Estevez, J., Georghiou, L., \& Yeow, J. (2014). Barriers to innovation through public procurement: A supplier perspective. Technovation, 34(10), 631-645. http://dx.doi.org/10.1016/j. technovation.2014.04.003

Vetoshkina, E. Yu., \& Tukhvatullin, R. Sh. (2014). The Problem of Accounting for the Costs Incurred after the Initial Recognition of an Intangible Asset. Mediterranean Journal of Social Sciences, 5(24), 52-56. http://dx.doi.org/10.5901/mjss.2014.v5n24p52

\section{Copyrights}

Copyright for this article is retained by the author(s), with first publication rights granted to the journal.

This is an open-access article distributed under the terms and conditions of the Creative Commons Attribution license (http://creativecommons.org/licenses/by/3.0/). 